This article was downloaded by: [The University of Manchester Library]

On: 11 April 2014, At: 05:59

Publisher: Routledge

Informa Ltd Registered in England and Wales Registered Number: 1072954 Registered

office: Mortimer House, 37-41 Mortimer Street, London W1T 3J H, UK

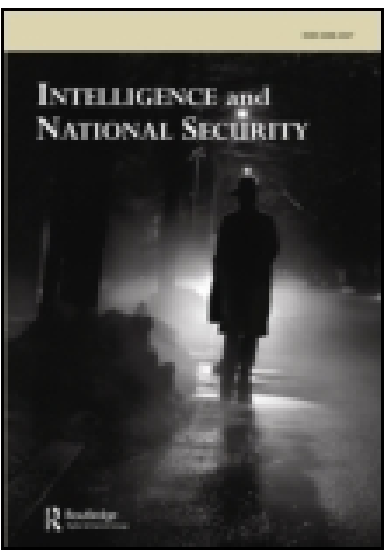

\title{
Intelligence and National Security
}

Publication details, including instructions for authors and subscription information:

http:// www.tandfonline.com/loi/fint20

\section{Conflict and Security in Contemporary Africa}

Carl Death

Published online: 01 Dec 2011.

To cite this article: Carl Death (2011) Conflict and Security in Contemporary Africa, Intelligence and National Security, 26:5, 737-745, DOI: 10.1080/02684527.2011.620792

To link to this article: http:// dx.doi.org/ 10.1080/02684527.2011.620792

\section{PLEASE SCROLL DOWN FOR ARTICLE}

Taylor \& Francis makes every effort to ensure the accuracy of all the information (the "Content") contained in the publications on our platform. However, Taylor \& Francis, our agents, and our licensors make no representations or warranties whatsoever as to the accuracy, completeness, or suitability for any purpose of the Content. Any opinions and views expressed in this publication are the opinions and views of the authors, and are not the views of or endorsed by Taylor \& Francis. The accuracy of the Content should not be relied upon and should be independently verified with primary sources of information. Taylor and Francis shall not be liable for any losses, actions, claims, proceedings, demands, costs, expenses, damages, and other liabilities whatsoever or howsoever caused arising directly or indirectly in connection with, in relation to or arising out of the use of the Content.

This article may be used for research, teaching, and private study purposes. Any substantial or systematic reproduction, redistribution, reselling, loan, sub-licensing, systematic supply, or distribution in any form to anyone is expressly forbidden. Terms \& Conditions of access and use can be found at http://www.tandfonline.com/page/termsand-conditions 


\title{
Conflict and Security in Contemporary Africa
}

\author{
CARL DEATH*
}

Ulf Engel and João Gomes Porto (eds.), Africa's New Peace and Security Architecture: Promoting Norms, Institutionalizing Solutions (Farnham: Ashgate, 2010). Pp.200. £22.50. Pb. ISBN 97807546676065.

Belachew Gebrewold, Anatomy of Violence: Understanding the Systems of Conflict and Violence in Africa (Farnham: Ashgate, 2009). Pp.274. £49.50. Hb. ISBN 9780754675280.

Malinda S. Smith (ed.), Securing Africa: Post-9/11 Discourses on Terrorism (Farnham: Ashgate, 2010). Pp.272. £49.50. Hb. ISBN 9780754675457.

On 11 July 2010 twin bomb blasts in Uganda tore through crowds watching the FIFA World Cup Final, one at an outdoor screening and one at an Ethiopian restaurant. The death toll would eventually pass $85 .^{1}$ The significance of al-Shabaab making their first attack on a site outside Somalia at the very moment when the world's media were praising South Africa for hosting a remarkably safe and secure 'African' World Cup could not have been more poignant, and the grief and terror in Kampala contrasted vividly with the joyful celebrations in Johannesburg where Nelson Mandela had greeted crowds at the tournament's closing ceremony. ${ }^{2}$

Such contrasts encapsulate many of the difficulties of analysing, explaining and understanding violence, terrorism and conflict in Africa.

\footnotetext{
*Email: crd@aber.ac.uk

${ }^{1}$ Flavia Nalubega, 'Uganda: World Cup Bombs Death Toll Hits 85 Mark', AllAfrica.com, 29 July 2010, < http://allafrica.com/stories/201007290965.html> (accessed 27 September 2011).

${ }^{2}$ Barry Moody, 'Mandela Drops in on World Cup Final', Mail and Guardian, 11 July 2010, $<$ http://www.mg.co.za/article/2010-07-11-mandela-drops-in-on-world-cup-final > (accessed 27 September 2011).
} 
The latest three contributions from Ashgate, which has a long history of publishing in this field, all seek to grapple with different aspects of this challenge. The diversity of the continent, ranging from relatively stable countries like South Africa, Botswana, Ghana and Tanzania where the army and the intelligence services maintain a low profile, to the seemingly interminable conflicts in Sudan, Somalia and the Democratic Republic of the Congo, highlight the ambition of the subtitle of Gebrewold's monograph: 'Understanding the systems of conflict and violence in Africa'. The Ashgate publishing stable has a long history of engaging with this difficult task however, with recent titles in the field including Humanitarian Intervention and Conflict Resolution in West Africa (2009), Africa and the War on Terrorism (2007), Ending Africa's Wars (2006), Uniting Africa: Building Regional Peace and Security Systems (2006), US Foreign Policy and the Horn of Africa (2006), Demilitarisation and Peace-building in Southern Africa (2004), The Military and Politics in Africa (2004), and African Interventionist States (2002). The latest additions to this list - under review here - continue the tradition of seeking to understand the roots and consequences of violent conflict in Africa.

\section{Building an Architecture for Peace}

The edited collection by Ulf Engel and João Gomes Porto, entitled Africa's New Peace and Security Architecture: Promoting Norms, Institutionalizing Solutions, is the clearest and most straightforward of these three titles. It provides both an overview, and a detailed examination and analysis, of the recent so-called Peace and Security Architecture (PSA) created by the African Union and the various Regional Economic Communities, and combines meticulous empirical and institutional discussion with a coherent theoretical approach, informed by the international relations (IR) literature on institutions and regimes. As such it is a remarkably well-focused collection, with interlocking chapters written by authorities on the subject or practitioners within the institutions themselves, bookended by a useful introduction and conclusion from the editors. The introduction provides the context for the shift from the Organisation of African Unity (OAU) to the African Union (AU), and draws attention to the significance of the AU's Constitutive Act (2000) which gives it the right to intervene in respect to 'grave circumstances, namely war crimes, genocide and crimes against humanity' (later amended to include 'serious threats to legitimate order'), as well as giving member states the right to ask the AU to intervene to restore peace and security (p.3). The significance of these provisions $-4 \mathrm{~h}$ and $4 \mathrm{j}-$ of the Constitutive Act are returned to in chapter after chapter, and are generally held by the contributors to signal the shift from a norm of 'non-intervention' to a norm of 'non-indifference' in African regional politics (e.g. p.61).

The following chapter by Fredrik Söderbaum and Björn Hettne constitutes an excellent resource for students and lecturers on the topic of regional African security, as well as drawing upon some of these authors' significant 
contributions to the field of 'new regionalism' over previous years. ${ }^{3}$ The regional perspective within which this collection is grounded is related to global dynamics, and the pros and cons of regional versus multilateral interventions are discussed, concluding that, whilst complementarity is the ideal, 'there are many reasons why a region-centred approach can be more relevant than an UN-led approach in the emerging global security context' (p.29). A closer engagement with some of these theoretical issues, and the global context, would have strengthened some of the rest of the chapters in this book. Having said this, the next chapter by Klaas van Walraven also stands out for its breadth and depth of historical detail. It provides an account of the OAU's record in peacekeeping between 1963 and 1993 from an author with great authority on the topic, and concludes perhaps counterintuitively that it was more interventionist and more successful than is generally recognized, before highlighting how some of the problems that did best the OAU (particularly regarding resources, budget support, and 'free-riding') have not been resolved by the AU.

The following chapters address various pillars of the PSA, including Kathryn Sturman and Aïssatou Hayatou on the Peace and Security Council, Tim Murithi and Charles Mwaura on the 'Panel of the Wise', and Jakkie Cilliers and Johann Pottgieter on the African Standby Force. The final chapter by Engel and Porto engages in more detail with IR theory and concludes that the PSA can be seen as an 'evolving peace and security regime', in which the internationalization of norms by political elites is leading to the institutionalization of more cooperative and peaceful behaviour (p.159).

Within the masses of sometimes dry, but frequently fascinating organizational and institutional detail in this book, readers of this journal might be particularly interested in the chapter on the Continental Early Warning System (CEWS) by a collective of seven contributors. The CEWS is intended to collate, analyse and report early information on potential conflicts and threats to peace to other pillars of the PSA and the AU. The chapter provides an account of how a hybrid methodology was developed to cope with the particular challenges of intelligence collection on such a large and diverse continent, with so many potential 'hot-spots', and vast disparities in the intelligence capacities of member countries. The devised methodology is based on three phases: 1) information collection and monitoring; 2) conflict and cooperation analysis; and 3) the formulation of continuous, iterative and interactive responses. It has sought to integrate African language sources into the data collection process, and includes constantly up-dated subnational area profiles (p.99). The chapter concludes by noting that staffing expertise and research and analysis capacity remain high priority areas (and there are several positions within the CEWS currently being advertised), and

\footnotetext{
${ }^{3}$ See Björn Hettne, 'Beyond the "New”' Regionalism', New Political Economy 10/4 (2005) pp.543-71; J. Andrew Grant and Fredrik Söderbaum (eds.), The New Regionalism in Africa (Aldershot: Ashgate 2003).
} 
the fundamental question of how and whether early warnings are translated into political action is raised (p.97) only too briefly.

This chapter encapsulates both the considerable strengths and minor weaknesses of this book. It is detailed, scholarly, well-focused, well-written and well-researched. Although it is critical in parts, it would be easy to finish this book feeling rather more optimistic than is usual when reading about peace and security in Africa. This in itself is no bad thing. Giving serious attention to the institutional innovations that are taking place under the auspices of the AU, and the development of norms of non-indifference and 'African solutions to Africa problems', is an important corrective to the stale tropes of Afro-pessimism and 'coming anarchy' that have been wheeled out for decades. Perhaps, however, the rather dry introduction and conclusion could have provided more contextualization regarding the extensive literature that does exist on some of the problems with a bureaucratic, institutional approach to conflict and peace-building in Africa, as well as some recognition of the socio-political dynamics which have meant that situations of insecurity, violence and conflict have worked to benefit certain groups and leaders. ${ }^{4}$ In short, whilst there is much useful technical and legalrational detail here, there is less attention paid to the politics of conflict in Africa.

\section{A Critical Politics of Terrorism and Africa}

The collection entitled Securing Africa: Post-9/11 Discourses on Terrorism, edited by Malinda S. Smith, explicitly positions itself within this more critical and political approach to conflict and security, and seeks to problematize many of the assumptions that underlie bureaucratic, technical and militaristic approaches to counter-terrorism and peace-keeping in Africa. In the preface Smith invites us to 'think critically, even dangerously about the implications for Africa of the moments and mobilizations that flowed from "9/11" and "the war on terror", and what potential, if any, such moments and mobilizations hold for securing Africa' (p.xvii). In contrast to the Engel and Porto collection Smith consciously seeks to question the role of the intellectual and the 'conceptual labour' that academics perform, drawing on theorists from Marx to Foucault, as well as V.Y. Mudimbe and Achille Mbembe (although the latter is described, mistakenly, as being Congolese rather than Cameroonian, p.xv), and the evolving fields of critical security studies and critical terrorism studies associated with scholars from Aberystwyth (embarrassingly referred to as

\footnotetext{
${ }^{4}$ For a selection of this more contextualised and critical literature, see Karen Ballentine and Jake Sherman (eds.), The Political Economy of Armed Conflict: Beyond Greed and Grievance (Boulder, CO: Lynne Rienner 2003); Patrick Chabal and Jean-Pascal Daloz, Africa Works: Disorder as Political Instrument (Oxford: James Currey 1999); Richard Jackson, 'Violent Internal Conflict and the African State: Towards a Framework of Analysis', Journal of Contemporary African Studies 20/2 (2002) pp.29-52.
} 
'the Welch [sic] School' by Smith, p.5). This more critical perspective throws up some interesting details and insights - such as the fact that Nelson Mandela and other African National Congress (ANC) members remained on the United States' terrorist watch list until 2008 (p.14) - and the book's contributors ask consistently important and difficult questions. However, the answers offered are not always as satisfying as might have been hoped, and frequent typographical errors and some inconsistency of focus undermine the collection's potential in places. For example, the striking lack of attention given to the various potential meanings of the titular term 'Securing Africa' in the preface, first or last chapter (all by Smith) is baffling, as is the absence of any discussion of Africa at all in large sections of these chapters (pp.ix-xv, 1-10, 193-200, 202-8, 214-21). Some more sustained and coherent justification of the book's scope and focus, and an explanation of why post 9/11 discourses on terror are particularly important in the production or securing of 'Africa', would have helped this rather disparate collection, beyond the anecdotal fact that Smith was in Johannesburg watching CNN when the planes flew into the Twin Towers on $9 / 11$ (p.xix).

The outstanding chapter in the first half of the book is written by Mike McGovern and addresses Islamism and counter-terrorism in West Africa's Sahara-Sahel region, in particular the Trans-Saharan Counter Terrorism Partnership (TSCTP). By contrasting the US tendency to see terrorists everywhere with equally polarized claims that the CIA and local governments have staged any North African violence, McGovern shows expertly how the complex sandstorm of Saharan politics is more variegated than either of these black-and-white pictures. He concludes that the overall threat of Jihadi activity in the region is small, but not non-existent, and many of the violent groups have essentially local grievances although they are united by a shared (and growing) anti-American sentiment (p.81). His detailed ethnographic and historical research on the region contrasts with some of the other more rhetorical chapters, and shows fascinatingly how informal political economies - the illicit Saharan cigarette trade, for example, is worth US $\$ 1$ billion per year - link into broader networks of violence, poverty, and religion (p.88). Other chapters in the first half of the book include a well-written, angry and impassioned contribution from Mustapha Marrouchi, influenced by Edward Said; a provocative and original chapter by Oladosu Afis Ayinde, which is ultimately too under-developed to convince the reader that 'any space of injustice, dishonesty and inhumanity is a space of terror' (p.65); an interesting, if largely second-hand account of political Islam in Somalia by Iqbal Jhazbhay; and a detailed exploration of Tanzanian anti-terrorism laws and policies by Faraj Abdallah Tamim and Malinda Smith.

The second half of the book apparently addresses 'Africa in Post-9/11 International Relations', but there is little sense of a coherent shift in focus. The standout chapter here is Afyare Abdi Elmi's account of US foreign policy towards Somalia from the Cold War onwards, which would make an excellent teaching text, and draws heavily on the work of notable scholars of 
the region such as Ken Menkhaus. ${ }^{5}$ The other chapters in this section Aderemi on bi- and uni-polar global orders, Chouala on African oil, Chacha and Marwa on Kenya, and Smith on the transition from Bush to Obama are somewhat patchy. Overall, whilst there is much of interest in this collection, there are relatively few areas in which the contributions go beyond the existing high standard of scholarship on Africa's place in the 'Global War on Terror' (McGovern's chapter is an obvious exception). The work of Rita Abrahamsen, Kevin Dunn, Michael Klare, Greg Mills, Daniel Volman and others have opened up the areas of engagement between the fields of African studies, IR, and security studies more effectively than many of these contributions manage, and they are only irregularly cited here. ${ }^{6}$ Recent research on the compliance of African states with the counterterrorism regime, for example, found significant differences between Uganda, Tanzania and Kenya, reflecting the important role of domestic constituencies and a higher degree of African agency to negotiate the terms of engagement with post-9/11 terrorism discourses than is sometimes implied in Securing Africa.

\section{Complexity and Conflict in Africa}

The third of the recent Ashgate contributions to the field, Anatomy of Violence: Understanding the Systems of Conflict and Violence in Africa by Belachew Gebrewold, takes a rather different tack on questions of peace, security and conflict in Africa. Rather than ask 'how is Africa's security architecture being implemented' (Engel and Porto), or 'what impact do global discourses of counter-terrorism have on Africa' (Smith), Gebrewold's monograph asks 'why have conflicts in DR Congo, Somalia and Sudan been so intractable?' (p.4). The hypothesis he sets out to prove is that 'DR Congo, Somalia and Sudan are in a protracted war because of three reasons: first, they are too weak to regulate the internal systemic interactions of various actors and factors; second, they are too weak to resist pressure from regional and global systemic impacts; third, their internal weaknesses facilitate

\footnotetext{
${ }^{5}$ See Ken Menkhaus, Somalia: State Collapse and the Threat of Terrorism (New York: Oxford University Press 2004).

${ }^{6}$ For a selection of some of the most engaging contributions, see Rita Abrahamsen, 'A Breeding Ground for Terrorists? Africa and Britain's "War on Terrorism", Review of African Political Economy 31/102 (2004) pp.677-84; Morten Bøås and Kevin C. Dunn (eds.), African Guerrillas: Raging Against the Machine (Boulder, CO: Lynne Rienner 2007); John Davies (ed.), Africa and the War on Terrorism (Aldershot: Ashgate 2007); Kevin C. Dunn and Timothy M. Shaw (eds.), Africa's Challenge to International Relations Theory (Basingstoke: Palgrave 2001); Greg Mills and Jeffrey Herbst, 'Africa, Terrorism and AFRICOM', The RUSI Journal 152/2 (2007) pp.40-5; Ian Taylor and Paul Williams (eds.), Africa in International Politics: External Involvement on the Continent (London: Routledge 2004); Michael Klare and Daniel Volman, 'America, China and the Scramble for Africa's Oil', Review of African Political Economy 33/106 (2006) pp.297-309.

${ }^{7}$ Beth Elise Whitaker, 'Compliance Among Weak States: Africa and the Counter-terrorism Regime', Review of International Studies 36/3 (2010) pp.639-62.
} 
regional and global involvements and interferences' (p.2). The overall argument, that intrastate, regional, and global systems all have a role to play in complex conflicts, has produced a complex book which combines dense elaboration of systems theory with impressively detailed accounts of these three theatres, but which overall does not entirely succeed in productively illuminating the causes of conflict or violence in Africa.

The short introduction begins with the collapse of Somalia in 1991, the 'mushrooming' of warlords, the 'indescribable' suffering of the population, the 'dramatic suffering' of the Sudanese, and then Zaire/Democratic Republic of Congo (DRC), 'famous for corruption and mismanagement' (p.1). Indeed the opening pages are almost Kaplan-esque. ${ }^{8}$ The brief references to other authors in the field tantalize rather than clarify Gebrewold's position (e.g. pp.2-3), and often awkward phrasing, frequent typographical errors, and the somewhat inconsistent usage of terms (like 'conflict', 'violence', and 'system') do not help the reader in negotiating what is an ambitious book.

The three theoretical chapters are lengthy, draw upon a dizzying array of theorists from Wallerstein and Waltz, Luhmann through Parsons, to Schmitt and Bull, and Deutsch and Tilly. The invocation of systems theory is densely complex - '[f]or any analysis of international relations as a system it is indispensable to discuss state as system or subsystem of the international relations system' (p.8) - and yet at points the theoretical concepts and framework seems almost misleading simple, such as when we are introduced to '[e]thnicism' as a 'socio-political disease' (p.25), or a rapid run-through of Africa from the 'democratically well-performing countries' (p.29) to the 'failed democracies' (p.34) on the basis of a definition of democracy taken from an (admittedly excellent) undergraduate textbook (pp.19-20). Yet, as the chapters progress, the theoretical discussions are increasingly supplemented with often fascinating empirical overviews, whether of the nuanced dimensions of Chinese involvement in Africa (pp.60-6), the vagaries of arms sales to the continent (pp.85-6), or the role of the Israeli military and intelligence services in South Sudan (pp.181, 211).

The bulk of the book's scholarly contribution comes in the four weighty chapters on the DRC, Somalia and Sudan (for reasons that are not entirely clear the global dimensions of the DRC conflict come in chapter four, whilst an extra chapter is provided on the global dimensions of Somalia and Sudan). The sheer scope of sources and historical detail supplied in these chapters is remarkable and reflected in the lengthy bibliography, and these cases may well be of interest to students or experts on these regions. The overall argument, however, suffers from the disconnect between this empirical material and the earlier theoretical debates, the heavy reliance on description rather than analysis, and the rather self-evident claim that

\footnotetext{
${ }^{8}$ Robert D. Kaplan, 'The Coming Anarchy: How Scarcity, Crime, Overpopulation, Tribalism, and Disease are Rapidly Destroying the Social Fabric of our Planet', The Atlantic Monthly, February 1994, < http://www.theatlantic.com/doc/199402/anarchy > (accessed 27 September 2011).
} 
understanding these conflicts requires paying attention to the intrastate, regional and global levels (see pp.129, 153, 179, 222). Gebrewold concludes that 'I have tried to underline that too little attention has been given to the systemic problems of conflict and violence in Africa' (p.222), but does not manage to explain who benefits from the systemic nature of conflict and violence in Africa, or what are the characteristics of these various systems that perpetuate conflict and violence. There is very little engagement with the detailed sociological and historical literature on systems of violence in Africa that such an argument would seem to imply, ${ }^{9}$ or the increasingly diverse literature on the systemic role of war within the liberal world order. ${ }^{10}$ The general message of the book - that wars are complex, multileveled, and involve a diverse range of scales and networks - is doubtlessly correct, but perhaps a reframed theoretical architecture could have enabled more to be said. This was typified in the final sentence, which concluded that '[c]onflicts in Africa must be seen as long-term destabilizing factors even to those who believe they are geographically far from them' (p.230). It prompted some regret that the book did not offer more reflection on the subject of whose interests this destabilization serves, which geographical differences matter more than others, and whether the very categories around which we conceptually organize the dimensions of conflicts (local, regional, and global) are the most useful for understanding violence in Africa.

\section{Conclusion: Africa and the World}

The diversity of approaches and perspectives offered in these three Ashgate books is a reflection of the vibrancy of the field of peace and conflict studies both in and on Africa. Yet they also raise important questions about the coherence of 'Africa' and the region as a conceptual focus, and they demand a careful consideration of what is gained and lost from generalizing at the state, continental and global levels. Gebrewold's identification of Sudan, Somalia and the DRC with 'Africa' (a common feature of publisher's desires for a title with a broad appeal) results in a portrayal of the continent which is

\footnotetext{
${ }^{9}$ For example, see Jean-François Bayart, The State in Africa: The Politics of the Belly (London: Longman 1993); Chabal and Daloz, Africa Works; Danny Hoffman, 'The Civilian Target in Sierra Leone and Liberia: Political Power, Military Strategy, and Humanitarian Intervention', African Affairs 103/411 (2004) pp.211-26; Paul Richards, Fighting for the Rain Forest: War, Youth and Resources in Sierra Leone (Oxford: James Currey 1996); Achille Mbembe, On the Postcolony (Berkeley, CA: University of California Press 2001); William Reno, Warlord Politics and African States (Boulder, CO: Lynne Rienner 1998); Alfred B. Zack-Williams, 'Sierra Leone: The Political Economy of Civil War 1991-1998', Third World Quarterly 20/1 (1999) pp.143-62.

${ }^{10}$ David Chandler, 'The Responsibility to Protect: Imposing the "Liberal Peace", International Peacekeeping 11/1 (2004) pp.59-81; Simon Dalby, 'Regions, Strategy and Empire in the Global War on Terror', Geopolitics 12/4 (2007) pp.586-606; Mark Duffield, Global Governance and the New Wars (London: Zed Books 2001); Oliver P. Richmond, 'The Problem of Peace: Understanding the "Liberal Peace", Conflict, Security and Development 6/ 3 (2006) pp.291-314.
} 
almost unrecognizable from the far more optimistic picture offered by Engel and Porto's volume. The regional viewpoint Engel and Porto offer on the African Union's Peace and Security Architecture contrasts with the much more globally situated perspectives the Smith volume provides. Such inevitable contrasts recall those shockingly different yet parallel images from 11 July 2010: as the ex-Umkhonto we Sizwe 'terrorist' and Nobel Peace Prize winner Nelson Mandela took to the field in celebration of the successful 'African' World Cup Finals, al-Shabaab militants were killing 85 innocent spectators in Kampala. In a continent of such contrasts, the value of regional analyses and generalizations, offered by all three books in their different ways, remain inevitably partial, fragmentary, and contradictory. Yet all three also manage to convince that they have important analytical, scholarly and political value. 